\title{
PENERAPAN KURIKULUM PHI (PENDIDIKAN HOLISTIK INTEGRAL) DALAM PEMBELAJARAN DI SMPIT LHI YOGYAKARTA
}

\author{
Sri Syafa'ati \\ UIN Sunan Kalijaga Yogyakarta \\ srisyafaati7@gmail.com
}

\begin{abstract}
This study aims to determite the application of the PHI curriculum in learning, as well as knowing the obstacles encountered and the strategies undertaken to overcome these obstacles in SMP IT Yogyakarta. The results of the study are; 1) The PHI curriculum is applied in every learning in SMPIT LHI Yogyakarta through the PBL (Project Based Learning) method, as well as being used as name of the subject, in which the main themes are based on the basic concepts, principles and models of Integral Holistic education. 2) Obtacles experienced namely; a) difficulties in translating books, b) there are no steps or guidelines in its application, c) not all teachers have educational background in PAI, d) it is still difficult to integrate public subjects with $P A I$, and e) there is no suitable book when applying PHI in learning. 3) Strategies undertaken by the school in overcoming various obstacles are; a) forming curriculum teams dan drafter, b) every odd semester there is always refreshing and upgrading/training related to the PHI curriculum, c) teachers look for various sources to be able to integrate in each subject, hold seminars and meetings regarding the introduction of the PHI curriculum, and d) looking at the same time making from various literacy sources to be used as material in teaching
\end{abstract}

Keywords: Curriculum, Holistic Integral Education, Learning

\begin{abstract}
Abstrak : Penelitian ini bertujuan untuk mengetahui penerapan kurikulum PHI dalam pembelajaran, sekaligus mengetahui hambatan yang dihadapi serta strategi yang dilakukan untuk mengatasi hambatan tersebut di SMP IT LHI Yogyakarta. Hasil penelitian ini ialah: 1) Kurikulum PHI diterapkan dalam setiap pembelajaran yang ada di SMPIT LHI Yogykarta melalui metode PBL (Project Based Learning), sekaligus dijadikan sebagai nama mata pelajaran, didalamnya dibuat tema pokok berdasarkan konsep dasar, prinsip-prinsip maupun model dari pendidikan Holistik Integral. 2) Hambatan yang dialami yakni; a) kesulitan dalam menerjemahkan buku, b) belum ada langkah-langkah maupun pedoman dalam penerapannya, c) tidak semua guru mempunyai latar belakang pendidikan PAI, d) masih sulit dalam mengintegrasikan mapel umum dengan PAI, dan e) belum ada buku yang sesuai jika menerapkan PHI dalam pembelajaran. 3) Strategi yang dilakukan pihak sekolah dalam mengatasi berbagai hambatan tersebut adalah; a) membentuk tim kurikulum dan konseptor, b) setiap semseter gasal selalu ada refresh dan penataran/pelatihan terkait kurikulum PHI, c) guru mencari berbagai sumber untuk dapat mengintegraskan pada setiap mapel, mengadakan seminar maupun rapat pertemuan terkait pengenalan kurikulum PHI, dan d) mencari sekaligus membuat dari berbagai sumber literasi untuk dijadikan bahan dalam mengajar.
\end{abstract}

Kata Kunci: Kurikulum, Pendidikan Holistik Integral, Pembelajaran

Islamika : Jurnal Keislaman dan Ilmu Pendidikan

Volume 2, Nomor 2, Juli 2020; 192-207

https:// ejournal.stitpn.ac.id/index.php/islamika 


\section{PENDAHULUAN}

Dalam sistem pendidikan, kurikulum merupakan salah satu komponen pokok. Sebab fungsinya sebagai pedoman pembelajaran serta alat untuk mengantarkan siswa mencapai tujuan pendidikan. Sedangkan bagi siswa, kurikulum pendorong berkembangnya berbagai potensi siswa dari seperangkat pengetahuan serta pengalaman belajar dengan mengembangkan intelektual, emosional, spiritual serta sosialnya untuk bekal di hidupnya. ${ }^{1}$

Peran pendidikan juga sangatlah penting sebagai pelaksana dari kurikulum yakni dalam mempengaruhi sekaligus membentuk kepribadian manusia. Sebab berhubungan langsung dalam pembentukan model manusia. ${ }^{2}$ Artinya, pendidikan sangat menentukan bagaimana karakter kepribadian manusia sebagai dampak dari proses pendidikan. Tentunya karakter-karakter yang positiflah yang sangat diinginkan dapat tercapai, sehingga manusia dapat menjalani hidup sesuai dengan tuntunan perkembangan zaman sesuai dengan cita-cita tujuan pendidikan nasional di Indonesia yakni berakhlaq, berilmu, cakap, kreatif dan bertanggung jawab. ${ }^{3}$

Namun pada kenyataannya, masih saja terjadi dekadensi moral pada anak didik, hal ini menjadi dasar bagi seluruh pihak untuk bertekad mengembangkan pembinaan pendidikan karakter di sekolah, akan tetapi pelaksanaannya belum optimal. ${ }^{4}$ Pada kenyataannya, materi pembelajaran sifatnya kognitif karena pengajarannya lebih banyak doktrinisasi, sehingga siswa hanya tahu teorinya namun prakteknya jauh dari harapan dan belum mampu membentuk karakter religius dan intelektualnya. Materinya yang siswa dapatkan terlepas dari konteks serta bertentangan dengan kehidupan yang beragam dan lebih penekanan pada keterkaitan serta integrasi. Oleh sebab itu untuk meningkatkan efektifitas hasil pembelajaran membutuhkan pendekatan yang mampu mengembangkan keberagaman semakin bermutu secara

1 Tahtimatir Rizkiyah, "Implementasi Pendidikan Holistik Dalam Kurikulum Pendidikan Islam, Jurnal Hikmatuna," Hikmatuna 2, No 1 (2017), hlm 2.

${ }^{2}$ Nana Syaodih Sukmadinata, Pengembangan Kurikulum Teori Dan Praktek (Bandung: PT Remaja Rosdakarya, 2013), 38.

${ }^{3}$ Kemendikbud, "UU SISDIKNAS Nomor 20 Tahun 2003," KEMENDIKBUD, 2013.

${ }^{4}$ Hendro Widodo and Avanti Vera Risti P, "Pendidikan Karakter Holistik Integratif Di PAUD Terpadu 'Aisyiyah Nur'Aini Ngampilan Yogyakarta," AL-ATHFAL: JURNAL PENDIDIKAN ANAK 3, No 2 (2017), https://doi.org/10.14421/al-athfal.2017.32-03, hlm. 136-137. 
terpadu. ${ }^{5}$ Istilah Terpadu menjadi jawaban sekaligus kritik umat Islam terhadap praktik pendidikan sekuler dan dikotomis yang selama ini terjadi. ${ }^{6}$ Misalnya dalam pembelajaran PAI dan ilmu umum, di sekolah umum pelajaran PAI hanya diajarkan pada porsi kecil sehingga para orang tua khawatir tentang kesholehan anaknya, betolak belakang jika di madrasah PAI diajarkan lebih luas tetapi khawatir jika urusan dunia sulit untuk didapat. ${ }^{7}$

Maka jelaslah bahwa masyarakat menghendaki adanya lembaga pendidikan yang mampu memberi bekal bagi subjek didik untuk dapat menghadapi perkembangan zaman. Yakni lembaga yang mampu memadukan antara pendidikan modern sebagai respons terhadap perkembangan zaman dan pendidikan agama yang kuat sebagai landasan dalam pembentukan moral dalam menghadapi dampak perkembangan zaman. ${ }^{8}$

Dari berbagai fakta di atas maka pendidikan perlu adanya metode pendidikan yang membangun manusia secara keseluruhan dan utuh dengan mengembangkan berbagai potensi manusia yakni disebut pendidikan holistik. ${ }^{9}$ Sedangkan perkembangan kurikulum saat ini maupun yang akan datang perlu adanya menggunakan pendekatan integrated curriculum. Integrasi yang berarti unit, dimaksudkan mencakup perbuatan, koordinasi, harmoni, dan kebulatan keseluruhan. Integrated kurikulum tidak membatasi mata pelajaran sekaligus menyajikan mata pelajaran dalam bentuk unit atau keseluruhan. ${ }^{10}$

Jika dilihat dari sistem pembelajaran di SMIPT LHI Yogyakarta maka pembelajarannya tidak seperti pada sekolah-sekolah pada umumnya. Karena dari materi yang ada misalnya mapel PAI, biologi, sejarah dan lainnya tidak terpisah secara hlm. 22 .

5 Qumruin Nurul Laila, "Pemikiran Pendidikan Moral Albert Bandura" Volume III (2015),

${ }^{6}$ Ricky Satria Wiranata, "Konsep Pendidikan Agama Islam Berbasis Islam Terpadu Aalisis Terhadap Isi Kurikulum SDIT BIAS Indonesia Tahun 2018," Abdau: Jurnal Pendidikan Madrasah Ibtidaiyah 2, No 1 (2019), hlm. 24.

${ }^{7}$ Ibid., hlm. 26.

8 Suyatno, "Sekolah Islam Terpadu; Filsafat, Ideologi, Dan Tren Baru Pendidikan Islam Di Indonesia," Jurnal Pendidikan Islam 2, No 2 (2013), hlm. 357-58, https://doi.org/10.14421/jpi.2013.22.355-377.

9 Jejen Musafah, Pendidikan Holistik Pendekatan Lintas Perspektif (Jakarta: Kencana, 2012), hlm. 114-115.

10 Mohamad Agung Rokhimawan, "ANALISIS SWOT KURIKULUM PRODI PGMI MENYONGSONG PEMBANGUNAN UIN SUNAN KALIJAGA YOGYAKARTA 2038 YANG BERVISI INTEGRASI-INTERKONEKTIF," AL-BID AYAH: Jurnal Pendidikan Dasar Islam 7, No 1 (2015), hlm. 6. 
sendiri-sendiri, artinya tidak dinamakan sebagai mapel PAI, biologi dan lain sebagainya, akan tetapi mapelnya dinamakan PBL (Project Based Learning). Di dalam PBL ini pembelajaran dari semua mapel umum dikaitkan dengan mapel PAI secara holistik dan integral. Oleh sebab itu, karena hal ini adalah sesuatu yang baru dan penting untuk mengungkap bagaimana kurikulum PHI tersebut diterapkan.

\section{METODE}

Penelitian ini merupakan penelitian lapangan (field research) yang menggunakan pendekatan kualitatif. Penelitian kualitatif adalah penelitian yang temuan-temuannya tidak diperoleh melalui prosedur statistik atau bentuk hitungan lainnya ${ }^{11}$, dan juga karena penelitian ini berusaha menggambarkan serta menginterpretasikan objek sesuai dengan apa adanya. ${ }^{12}$ Yakni menggambarkan obyek secara nyata dan apa adanya tentang pelaksanaan kurikulum Pendidikan Holistik-Integral dalam pembelajaran di SMPIT LHI Yogyakarta.

Pengumpulan data dilakukan dengan tiga metode, yaitu observasi, wawancara, serta dokumentasi. Observasi dilakukan di SMPIT LHI Yogyakarta yang meliputi observasi di lapangan (kelas). Wawancara dilaksanakan pada narasumber yakni kepala sekolah, waka kurikulum, guru PAI dan siswa SMPIT LHI Yogyakarta. Sedangkan dokumentasi meliputi mengumpulkan segala sumber yakni dokumen-dokumen yang sesuai dengan penelitian ini.

\section{HASIL DAN PEMBAHASAN}

\section{Konsep Dasar Kurikulum Pendidikan Holistik-Integral}

Harapan dari pendidikan adalah dapat membangun kehidupan di masa yang akan datang, yakni yang dapat mengembangkan potensi subjek didik agar mampu menghadapi berbagai masalah dalam kehidupannya. Potensi yang dimaksud mencakup potensi nurani maupun kompetensi subjek didik. Dalam hal ini maka perlu

11 Anselem Strauss and Juliet Corbin, Dasar-Dasar Penelitian Kualitatif, Terj. Muhammad Shodiq Dan Imam Muttaqin (Yogyakarta: Pustaka Pelajar, 2009), hlm. 4.

12 Sukardi, Metodologi Penelitian Pendidikan; Kompetensi Dan Praktiknya, 7th ed. (Jakarta: Bumi Aksara, 2009), hlm 15. 
adanya model pendidikan yang dirancang secara sistematis dan menyeluruh (holistik). Dengan demikian, pendidikan menjadi wahana strategis bagi upaya pengembangan seluruh potensi individu, sehingga dapat tercapai dalam membangun manusia seutuhnya. Ada beberapa cara dalam penerapan pendidikan holistik, diantaranya dengan menerapkan pembelajaran terintegrasi/terpadu (integrated learning) yakni dengan memadukan berbagai materi dalam satu sajian pembelajaran. ${ }^{13}$

Dikutip oleh Jejen Musfah, menurut Joni T. R., pembelajaran terpadu merupakan suatu sistem pembelajaran yang memungkinkan siswa secara individu maupun kelompok aktif mencari, menggali dan menemukan konsep dan prinsip keilmuan secara holistik, bermakna dan autentik. Pembelajaran ini akan terjadi apabila peristiwa-peristiwa autentik atau eksplorasi topik/tema menjadi pengendali dalam kegiatan pembelajaran, sehingga siswa belajar tentang proses dan isi beberapa mata pelajaran secara serempak.

Apabila dikaitkan dengan tingkat perkembangan anak, pembelajaran terpadu merupakan pendekatan pembelajaran yang memperhatikan serta menyesuaikan pemberian konsep sesuai tingkat perkembangan anak. Pendekatan ini berangkat dari teori pembelajaran yang menolak drill-system sebagai dasar pembentukan pengetahuan struktural intelektual anak. ${ }^{14}$

Maka dapat disimpulkan bahwa pembelajaran terpadu ialah; (1) pembelajaran yang bermula pada pusat perhatian yakni suatu tema yang digunakan untuk memahami berbagai gejala serta konsep lain yang meliputi bidang studi yang bersangkutan dari bidang studi lain; (2) pembelajaran dengan pendekatan yang menghubungkan berbagai bidang studi yang berkaiatan dengan dunia nyata di sekitarnya serta dalam rentang kemampuan siswa; (3) suatu cara untuk mengembangkan pengetahuan serta keterampilan siswa secara simultan dan (4) pembelajaran terpadu merakit dan menghubungkan sejumlah konsep dalam beberapa bidang studi yang berbeda, dengan harapan siswa akan belajar dengan lebih baik sekaligus bermakna. ${ }^{15}$

${ }^{13}$ Musafah, Pendidikan Holistik Pendekatan Lintas Perspektif, hlm 177-178.

${ }^{14}$ Ibid., hlm. 177-179.

15 Zubaedi, Desain Pendidikan Karakter; Konsepsi Dan Aplikasinya Dalam Lembaga Pendidikan (Jakarta: Prenada Media Group, 2011), hlm. 267. 
Pembelajaran terpadu akan terjadi jika kejadian yang wajar atau eksplorasi suatu topik merupakan inti dalam pengembangan kurikulum. Dengan berperan aktif dalam eksplorasi tersebut, siswa akan mempelajari materi ajar serta proses belajar beberapa bidang studi dalam waktu yang bersamaan.

Maka jelaslah bahwa sebagai pemicu dalam pelaksanaan pembelajaran terpadu adalah melalui eksplorasi topik yang kemudian diangkatlah suatu tema tertentu. Kegiatan pembelajaran berlangsung di seputar tema kemudian baru membahas masalah konsep-konsep pokok yang terkait tema.

Dari beberapa pemaknaan terhadap konsep pembelajaran terpadu, intinya terletak sejauh mana kemampuan seorang pendidik untuk dapat mengemas kurikulum pembelajarannya, sehingga tercipta kesatupaduan antara satu tema/topik dengan tema/topik yang lain atau satu konsep dengan konsep yang lain pula. Para pendidik menyebutnya dengan istilah kurikulum terintegrasi/terpadu (integrated curriculum). ${ }^{16}$

Kurikulum terintegrasi, sering dikenal dengan istilah interdisciplinary teaching, thematically teaching, dan synergetic teaching. Kurikulum ini dapat memberikan peluang kepada siswa untuk menarik kesimpulan dari berbagai sumber informasi berbeda mengenai suatu tema, serta sekaligus dapat memecahkan masalah dengan memperhatikan faktor-faktor dari berbagai aspek. Selain itu proses belajar menjadi relevan dan kontekstual sehingga berarti bagi siswa dan membuat siswa dapat berpartisipasi aktif sehingga seluruh dimensi manusia terlibat aktif (fisik, moral, emosi dan akademik). ${ }^{17}$

1. Model Holistik-Integral menurut Fogarty

Konsep dalam pendekatan terpadu di Indonesia yang saat ini berkembang dan dipelajari adalah model yang diterapkan oleh Robin Fogarty, yang menyatakan bahwa terdapat 10 model dalam pembelajaran terintegrasi, ${ }^{18}$ berikut penjelasannya:

a. Model Fragmented; model pembelajaran terpisah, yang memisahkan antara berbagai bidang ilmu.

${ }^{16}$ Musafah, Pendidikan Holistik Pendekatan Lintas Perspektif, hlm. 179-180.

${ }^{17}$ Ibid., hlm. 181.

18 Zubaedi, Desain Pendidikan Karakter; Konsepsi Dan Aplikasinya Dalam Lembaga Pendidikan, hlm 265. 
b. Model Connected; menghubungkan mata pelajaran yang memiliki keterkaitan/yang bersangkutan saja tanpa disiplin ilmu lain.

c. Model Nested; diharapkan ada multi-nilai yang yang saling berhubungan dalam pembelajaran.

d. Model Sequenced: tema dan unit-unit ilmu ditata kembali, diurutkan serta dihubungkan sampai cocok diantara yang lain atau membingkai dua disiplin ilmu.

e. Model Shared; menghubungkan dua disiplin ilmu untuk mencapai beberapa nilai dalam satu pembelajaran.

f. Model Webbed; memadukan berbagai mata pelajaran yang dibingkai dalam satu tema.

g. Model Threaded; merangkai berbagai materi yang dibahas pada berbagai mata pelajaran.

h. Model Integrated; merangkai berbagai mata pelajaran yang diperkuat pada proses team teaching.

i. Model Immersed; keahlian subjek didik dalam memadukan berbagai berbagai bidang ilmu yang hasilnya mampu diterapkan pada kehidupan kesehariannya.

j. Model Networked; pembelajaran yang melibatkan kerjasama siswa dengan pakar atau ahli untuk mendukung proyek yang dikaji. ${ }^{19}$

2. Prinsip Dasar Pendidikan Holistik Integral

Menurut Trianto mengutip dari Jejen Musfah, secara umum prinsip-prinsip pembelajaran terpadu dapat dikelompokkan menjadi empat hal, yakni sebagai berikut:

a. Prinsip Penggalian Tema

Prinsip utama dalam pembelajaran integral adalah prinsip penggalian tema. Yakni, tema-tema yang saling bersusun dan ada keterkaitan menjadi target utama dalam pembelajaran. Maka tema hendaklah memperhatikan beberapa persyaratan sebagai berikut ${ }^{20}$ :

${ }^{19}$ Rafiqa Noviyani, "Implementasi Pendidikan Holistik Integral Di SMPIT LHI Yogyakarta" (UIN Sunan Kalijaga yogyakarta, 2018), hlm. 43-58.

${ }^{20}$ Musafah, Pendidikan Holistik. Pendekatan Lintas Perspektif, hlm. 183-184. 
1) Tema hendaklah tidak terlalu luas, namun dengan mudah dapat digunakan untuk memadukan banyak mata pelajaran.

2) Tema harus bermakna, yakni tema yang dipilih untuk dikaji harus memberikan bekal bagi siswa untuk belajar selanjutnya.

3) Tema harus disesuaikan dengan tingkat perkembangan psikologis anak.

4) Tema dikembangkan harus menampung sebagian besar minat anak.

5) Tema yang dipilih hendaknya mempertimbangkan peristiwa-peristiwa autentik yang terjadi dalam rentang waktu belajar.

6) Tema yang dipilih hendaknya mempertimbangkan kurikulum yang berlaku serta sesuai harapan masyarakat.

7) Tema yang dipilih hendaknya juga mempertimbangkan ketersediaan sumber belajar.

b. Prinsip Pengelolaan Pembelajaran

Pengelolaan pembelajaran dapat optimal apabila guru mampu menempatkan dirinya dalam keseluruhan proses. Yakni guru harus mampu menempatkan diri sebagai fasilitator dan mediator dalam proses pembelajaran. Maka peran guru adalah sebagai berikut:

1) Guru hendaknya jangan menjadi pemain tunggal (single actor) yang mendominasi pembicaraan dalam keseluruhan proses belajar.

2) Pemberian tanggung jawab individu dan kelompok harus jelas dalam setiap tugas yang menuntut adanya kerja sama kelompok.

3) Guru perlu mengakomodasi terhadap ide-ide yang terkadang sama sekali tidak terpikirkan dalam perencanaan.

c. Prinsip Evaluasi

Evaluasi pada dasarnya menjadi fokus dalam setiap kegiatan. Bagaimana suatu kerja dapat diketahui hasilnya apabila tidak dilakukan evaluasi. Dalam hal ini, ketika melaksanakan evaluasi dalam pembelajaran terpadu perlu beberapa langkah positif antara lain:

1) Memberi kesempatan kepada siswa untuk melakukan evaluasi diri di samping bentuk evaluasi lainnya. 
2) Guru perlu mengajak para siswa untuk mengevaluasi perolehan belajar yang telah dicapai berdasarkan kriteria keberhasilan pencapaian tujuan yang akan dicapai. ${ }^{21}$

d. Prinsip Reaksi

Dampak pengiring (nurturant effect) yang penting bagi perilaku secara sadar belum tersentuh guru dalam Kegiatan Belajar Mengajar. Karena itu, guru dituntut agar mampu merencanakan dan melaksanakan pembelajaran sehingga tercapai secara tuntas tujuan-tujuan pembelajaran. Guru harus bereaksi terhadap akal siswa dalam semua peristiwa serta tidak mengarahkan aspek yang sempit ke suatu kesatuan yang utuh dan bermakna. Pembelajaran terpadu memungkinkan hal ini dan guru hendaknya menemukan kiat-kiat untuk memunculkan ke permukaan hal-hal yang dicapai melalui dampak pengiring. ${ }^{22}$

\section{Penerapan Kurikulum PHI di SMIPT LHI Yogyakarta}

Sekolah Menengah Pertama Islam Terpadu LHI Yogyakarta merupakan sekolah yang bernaung di bawah yayasan LHI. Sekolah ini menggunakan kurikulum sendiri yaitu kurikulum Pendidikan Holistik dan Integral, penyusunannya dari kurikulum pemerintah/dinas seperti K-13 lalu ada tambahan dari sekolah yang menjadikan ke-khasannya. Jadi kurikulum PHI di SMPIT LHI Yogyakarta adalah perpaduan antara kurikulum Dinas, UK serta dari ke-khasan sekolah yakni 7 literasi (kecakapan). Kurikulum ini mulai diterapkan di SMIPT LHI Yogyakarta semenjak 2 tahun yang lalu, yakni dari tahun 2017-2019 (sampai sekarang).

Kerangka keilmuan kurikulum ini merupakan kurikulum nasional (Kurikulum 2013) yang diperkaya dengan British National Curriculum yang meliputi pengetahuan, keterampilan dan pemahaman dalam 10 bidang studi. British National Curriculum mencakup literasi (bahasa dan sastra), matematika, ilmu pengetahuan alam, desain, teknologi informasi dan komunikasi, sejarah, geografi, seni, musik, dan pendidikan jasmani. Adapun pendidikan agama Islam bersumber dari kurikulum nasional yang

${ }^{21}$ Ibid., hlm. 184.

${ }^{22}$ Ibid., hlm. 184-185. 
diperkaya dengan IBERR (The International Board of Educational Research and Resources) dan program BTHCQ (Baca Tulis Hafal Cinta Al Qur'an) dengan Metode UMMI.

Berikut hasil dan penjelasan mengenai penerapan kurikulum PHI:

a. Proses Penyusunan Kurikulum PHI

Perencanaan dalam penyusunan Kurikulum PHI sesuai dengan prosedur dari dinas. Disusun berdasarkan draft-draft kurikulum dari sekolah, apa saja yang akan ditambahkan, lalu barulah diuji publik. Dengan mengundang dari dinas, komite, guru, yayasan dan pihak-pihak yang terkait di dalamnya untuk nantinya ada masukan dari berbagai pihak tersebut, dan jika sudah di uji publik (dipresentasikan) apabila sudah memenuhi syarat maka disahkan oleh dinas.

Sedangkan acuan untuk perencanaan penyusunan kurikulum adalah dari visi misi sekolah, program-program sekolah, standar SKL, Dinas dan dari tim pengembang kurikulum (kepala sekolah, waka kurikulum, staf-staf sekolah, guru) untuk menyusun kurikulum dengan memasukkan ke-khasan sekolah.

Kurikulum yang disusun juga disesuaikan dengan kebutuhan siswa, misalnya dengan bisa membaca al-Qur'an, sehingga pengembangannya lebih difokuskan di kelas VII, sebab kebutuhan siswa pada tahap usia ini (baligh) lebih kepada tumbuh kembangnya, mengenal diri sendiri dengan konsep Allah menciptakan manusia, dari mana asal manusia dan sebagainya. Jadi membangun kesadaran dalam beribadah karena apa, bagaimana, serta tanggung jawabnya sebagai umat Islam apa saja. Dan masih banyak lagi contoh lainnya yang disesuaikan dengan perkembangan siswa.

b. Pengembangan Kurikulum PHI

Dalam pengembangan kurikulum PHI di sekolah, dikembangkan pada aktivitas pembelajaran yang penyusunannya didesain oleh tim angkatan kelas, misal di kelas VII tim penyusunnya dari guru PAI dan guru Biologi sebab tema yang diambil di kelas VII semester gasal adalah Tubuhku Amanah-Mu. Maka suksesnya kegiatan tergantung guru yang mengampu pembelajaran yang dilaksanakan sesuai tema yang dikembangkan dari kurikulum. Tema tersebut kemudian disusun ke dalam kegiatan pekanan.

Pengembangan kurikulum juga dilakukan dengan kerjasama antara yayasan, tim pengembang kurikulum, lalu ke guru-guru dan orang tua siswa juga. 
Bagi siswa yang ikut asrama, dua minggu sekali pulang. Pada saat itu akan disampaikan kepada orang tua apa saja tugas anak-anak, sehingga orang tua ikut terlibat di dalamnya, bisa sebagai fasilitator mapun pemantau kegiatan siswa di rumah. Jadi tiga bulan pertama ada laporan dari sekolah, dan disampaikan kepada orang tua yang nantianya apa saja yang bisa dibantu dari pihak orang tua. maka bukan hanya guru yang berperan dalam pengembangan kurikulum, namun juga dari para wali murid diikut sertakan.

Selain itu pengembangan juga dari SKL, KI-KD, RPP dan sebagainya itu dikembangkan, yakni terutama di lapangan, sehingga guru-guru lebih mengembangkan aktivitas-aktivitas programnya. Jadi dengan adanya tim-tim guru, dibentuklah berbagai kegiatan untuk menunjang pengembangan kurikulum sekolah.

Untuk evaluasi dalam pengembangan kurikulum dilaksanakan pada kegiatan uji publik yang dilakukan setiap tahunnya yakni setiap semseter 1 (gasal). Dari uji publik dilihat apa saja yang berubah dari tahun sebelumnya (kurikulum yang telah dilaksanakan), dari segi indikator baru yang akan dimasukkan, maupun dasar hukumnya sudah tidak update, program-program apa yang belum masuk dan lain sebagainya yang dijadikan bahan masukan dan pertimbangan untuk penyusunan revisian kekurangan apa saja dalam dalam pengembangan kurikulum PHI sebelumnya.

c. Penerapan Kurikulum PHI dalam Kegiatan Pembelajaran

Kurikulum PHI diterapkan dalam semua kegiatan di sekolah. Yakni mata pelajaran umum diintegrasikan dengan pelajaran PAI. Kegiatan ini di SMPIT LHI Yogyakarta dinamakan PBL atau Project Based Learning. PBL bukan hanya sebuah metode, namun dijadikan nama mata pelajaran. Dalam PBL semua mata pelajaran dikaitkan dengan PAI. PAI di breakdown dalam seluruh kegiatan pembelajaran. Jadi di kurikulum PHI semua mapel tidak berdiri sendiri. Misalnya, mapel Fiqih, Aqidah, Biologi tidak sendiri-sendiri. Tapi semua mapel harus ada unsur agamanya.

Misalnya dalam kegiatan PBL tersebut ada tematik. Di kelas VII temanya tentang Tubuhku Amanuh-MU. Jadi Di materi ini siswa mengenal bagaimana penciptaan manusia, terkait dengan makanannya, mengenal zat adiktif apa saja, 
nanti searching sendiri dari siswa. Ada worksheetnya (lembar kerja) sendiri, dari banyak sumber. Ada pula praktek langsung ke lapangan yaitu ke BPOM. Jadi siswa langsung mengidentifikasi makanan yang ia makan apa saja kandungan di dalamnya. Sehingga tidak hanya tahu konsep-konsep yang sudah ada dari materi, namun siswa menemukan atau membuktikan sendiri kandungan yang ada dalam makannya mereka.

PAI terdiri dari banyak sekali jam yakni 8 jam pelajaran. Karena PAI adalah ruhnya. Jadi mapel PAI bagimana bisa di integrasikan dengan semua mapel yang diajarkan di sekolah. Jadi semua mapel tidak keluarnya dari ruhnya, yakni pelajaran PAI. Tujuh literasi atau tujuan dari sekolah diasah dengan project bersama, lebih pada praktek. Mendiscovery seperti pada kurikulum 2013. Jadi menemukan terlebih dahulu, materi/teorinya di belakang.

Dari kegiatan PBL mapel diintegrasikan, yakni ada Biologi, Fiqih, dan Aqidah Akhlak. Pembelajaran juga dikemas dengan berbagai macam kegiatan, mulai dari melihat video, studi literasi, praktek, proyek/tugas, dan presentasi. Selain itu, tema yang diambil juga sesuai dengan tujuh literasi yang hendak dicapai yakni literasi ke-4 tentang kecakapan fisik, sebab pada tahap umur ini siswa sudah baligh, maka perlu adanya tema yang berkaitan dengan kebutuhan siswa. Di sub tema selanjutnya yaitu makanan halal dan haram, zat aditif makanan, dan tanaman obat keluarga. Jadi fisik siswa diperhatikan juga, dari mulai aurat, makanan yang halal dan toyib bagi manusia, zat-zat yang terkandung dalam makanan, serta kesehatannya dengan menyadari, dan mengkaji mensyukuri obat alami yang telah Allah sediakan bagi manusia.

Maka jelas sekali terlihat pembelajaran holistik integral ini yang memungkinkan siswa secara individu maupun kelompok aktif mencari, menggali dan menemukan konsep dan prinsip keilmuan secara holistik, bermakna dan autentik. Pembelajaran ini akan terjadi apabila peristiwa-peristiwa autentik atau eksplorasi topik/tema menjadi pengendali dalam kegiatan pembelajaran, sehingga siswa belajar tentang proses dan isi beberapa mata pelajaran secara serempak. Selain itu juga memperhatikan perkembangan anak maupun kebutuhannya, pemusatan pada satu tema yang konsepnya berkaitan dengan pelajaran lain, semua materi terkait dan terhubung dengan bidang lain yang 
berujuan agar pembelajaran lebih bermakna, bidang studi berkaitan dengan dunia nyata serta kemampuan siswa, dan kegiatan bertujuan mengembangkan pengetahuan dan keterampilan siswa (contoh: membuat pamflet tentang wudu, membuat laporan penelitian dalam bentuk poster tentang resep makanan/minuman halal dan toyib dan praktek memasak resep tersebut, menguji zat makanan yang ada dalam makanan kemudian membuat laporan dan sosialisai terkait hasil eksperimennya, dan masih banyak lagi).

Seluruh kegiatan pembelajarannya yang dilaksanakan juga sudah sesuai dengan dasar, prinsip, karakteristik dan model yang dicanangkan Robin Forgaty. Selain itu model pembelajaran terintegrasi dengan pendekatan $7 \mathrm{M}$ diterapkan yang meliputi Mengagumi (Spiritual Aspect), Menghayati (Moral Aspect), Meneliti (Intellectual Aspect), Merealisasi (Physical Aspect), Mengkolaborasi (Interpersonal Aspect), Mengaktualisasi (Cultural Aspect), dan Memberi (Social Aspect).

\section{Hambatan dalam Penerapan Kurikulum PHI di SMIPT LHI Yogyakarta}

Hambatan-hambatan yang dialami dalam penerapan kurikulum PHI lebih kepada penerapannya dalam proses pembelajaran. Sebab, masih sedikit sekolah yang menerapkan kurikulum ini. Apalagi ditambah dengan ke-khasan sekolah yaitu tujuh kecakapan, sehingga kurikulum khas ini sebagai pembabat utama dalam penerapannya. Maka hambatan yang dialami adalah:

a. Untuk pelaksanannya tidak ada langkah-langkah maupun panduannya sehingga dari buku itu guru-guru menerterjemahkan sendiri.

b. Semuanya kegiatan yang sesuai prinsip maupun karakteristik dari kurikulum PHI belum terkonsep secara baik. Karena memang tidak ada/belum ada yang mengonsep.

c. Tidak semua guru mempunyai background PAI.

d. Sulit mengaitkan mapel umum dengan PAI atau mencari telaah ayat maupun hal lain yang berhubungan dengan mapel-mapel tertentu.

e. Karena semua mapel diintegrasikan dalam satu pembelajaran, maka tekadang siswa belum bisa menemukan maupun membedakan ini nama mata pelajaran apa, misalnya PAI yang Fiqih, Aqidah maupun biologi, atau lainnya. 
f. Orang tua belum yakin dan bahkan khawatir dengan pembelajaran yang diterapkan sesaui kurikulum PHI. Sebab pembelajarannya sangat berbeda dengan sekolah-sekolah lain dan tidak sesuai dengan mapel dari pemerintah dan takut akan ketinggalan materi yang diujikan pada Ujian Nasional.

g. Belum adanya buku yang tepat sesuai dengan pembelajaran yang diajarkan.

\section{Strategi untuk Mengatasi Hambatan dalam Penerapan Kurikulum PHI di SMIPT LHI Yogyakarta}

Untuk mengatasi berbagai hambatan di atas, maka dari pihak sekolah membuat strategi-strategi sebagai berikut:

a. Tim kurikulum (yayasan, kepala sekolah, waka kurikulum dan beberapa guru) menerjemahkan serta dibentuk tim konseptor dari tiap tim angkatan kelas sebagai pembuat konsep-konsep kegiatan pekanan sehingga semua guru dalam melaksanakan pembelajaran ada panduan serta langkah-langkahnya. Dan karena tidak semua guru berlatar pendidikan PAI. Konseptor kelas VII dari guru Biologi dan guru PAI.

b. Setiap awal semester gasal ada refresh terkait pelaksanaan kurikulum PHI. Bagi guru yang baru magang ada penataran dan pelatihan tentang PHI. Selalu ada evaluasi dalam setiap semester.

c. Guru mencari berbagai sumber dalam mengintegrasikan berbagai mata pelajaran.

d. Guru menstimulus siswa terkait pembelajaran masuk kategori mapel apa.

e. Meyakinkan orang tua dengan diadakannya seminar mapun pertemuan mengenai pemahaman kurikulum PHI.

f. Guru mencari dan membuat ringkasan dari berbagai sumber literasi terkait materi (untuk memudahkan siswa belajar) yang dibutuhkan pada pembelajaran. 


\section{KESIMPULAN}

Berdasarkan rumusan masalah, kerangka teori dan juga hasil penelitian maka penulis simpulkan:

1. Kurikulum PHI diterapkan dalam setiap pembelajaran yang ada di SMPIT LHI Yogykarta. Dengan menerapkan metode PBL (Project Based Learning), yang sekaligus dijadikan sebagai nama mata pelajaran, di dalamnya dibuat tema pokok, yakni Tubuhku Amanah-Mu (kelas VII) yang terdiri dari berbagai sub tema yakni Akil Baligh, Makanan Halal dan Haram, Zat Aditif Makanan dan Tanaman Obat Keluarga. Penerapannya juga sudah sesuai berdasarkan konsep dasar, prinsipprinsip maupun model dari pendidikan Holistik Integral. Yakni meliputi, materi terdiri dari tema pokok yang diintegrasikan antara ilmu umum serta agama, semua materi terhubung satu sama lain, sesuai dengan dunia nyata di sekitar siswa, konsep belajar bermakna, membangun berbagai keterampilan serta pengetahuan yakni 7 kecakapan.

2. Hambatan yang dialami dalam penerapan kurikulum PHI ini lebih kepada dalam proses pembelajaran dan pada beberapa hal lain yakni; kesulitan dalam menerjemahkan buku, tidak ada langkah-langkah maupun pedoman dalam penerapannya, tidak semua guru mempunyai latar belakang pendidikan PAI, masih sulit dalam mengintegrasikan mapel umum dengan PAI, siswa belum terbiasa dan terkadang belum bisa membedakan mapel apa yang sedang dikaji, keraguan orang tua murid pada kurikulum PHI, dan belum ada buku yang sesuai jika menerapkan PHI dalam pembelajaran

3. Strategi yang dilakukan pihak sekolah dalam mengatasi berbagai hambatan tersebut adalah membentuk tim kurikulum dan konseptor, setiap semseter gasal selalu ada refresh dan penataran/pelatihan terkait kurikulum PHI, guru memcari berbagai sumber untuk dapat mengintegraskan pada setiap mapel, mengadakan seminar maupun rapat pertemuan terkait pengenalan kurikulum PHI, dan mencari sekaligus membuat dari berbagai sumber literasi untuk dijadikan bahan dalam mengajar. 


\section{DAFTAR PUSTAKA}

Kemendikbud. "UU SISDIKNAS Nomor 20 Tahun 2003." KEMENDIKBUD, 2013.

Laila, Qumruin Nurul. "Pemikiran Pendidikan Moral Albert Bandura" Volume III (2015): 22.

Musafah, Jejen. Pendidikan Holistik Pendekatan Lintas Perspektif. Jakarta: Kencana, 2012.

Noviyani, Rafiqa. "Implementasi Pendidikan Holistik Integral Di SMPIT LHI Yogyakarta.” UIN Sunan Kalijaga yogyakarta, 2018.

Rizkiyah, Tahtimatir. "Implementasi Pendidikan Holistik Dalam Kurikulum Pendidikan Islam, Jurnal Hikmatuna.” Hikmatuna 2, No 1 (2017).

Rokhimawan, Mohamad Agung. "ANALISIS SWOT KURIKULUM PRODI PGMI MENYONGSONG PEMBANGUNAN UIN SUNAN KALIJAGA YOGYAKARTA 2038 YANG BERVISI INTEGRASI-INTERKONEKTIF." AL-BID AY AH: Jurnal Pendidikan Dasar Islam 7, No 1 (2015): 6.

Strauss, Anselem, and Juliet Corbin. Dasar-Dasar Penelitian Kualitatif, Terj. Mubammad Shodiq Dan Imam Muttaqin. Yogyakarta: Pustaka Pelajar, 2009.

Sukardi. Metodologi Penelitian Pendidikan; Kompetensi Dan Praktiknya. 7th ed. Jakarta: Bumi Aksara, 2009.

Sukmadinata, Nana Syaodih. Pengembangan Kurikulum Teori Dan Praktek. Bandung: PT Remaja Rosdakarya, 2013.

Suyatno. "Sekolah Islam Terpadu; Filsafat, Ideologi, Dan Tren Baru Pendidikan Islam Di Indonesia." Jurnal Pendidikan Islam 2, No 2 (2013): 357-58. https://doi.org/10.14421/jpi.2013.22.355-377.

Widodo, Hendro, and Avanti Vera Risti P. "Pendidikan Karakter Holistik Integratif Di PAUD Terpadu 'Aisyiyah Nur'Aini Ngampilan Yogyakarta." ALATHFAL: JURNAL PENDIDIKAN ANAK 3, No 2 (2017). https://doi.org/10.14421/al-athfal.2017.32-03.

Wiranata, Ricky Satria. "Konsep Pendidikan Agama Islam Berbasis Islam Terpadu Aalisis Terhadap Isi Kurikulum SDIT BIAS Indonesia Tahun 2018.” Abdau: Jurnal Pendidikan Madrasah Ibtidaiyah 2, No 1 (2019).

Zubaedi. Desain Pendidikan Karakter; Konsepsi Dan Aplikasinya Dalam Lembaga Pendidikan. Jakarta: Prenada Media Group, 2011. 